\title{
The Crown of Thorns: SARS-CoV-2
}

Nandini Chatterjee ${ }^{1}$, Anup K Bhattacharya ${ }^{2}$

Bengal Physician Journal (2021): 10.5005/jp-journals-10070-7023

The coronavirus disease-2019 (COVID-19) pandemic, which emerged in the remote province of Wuhan in China, has encompassed all the continents with a vehement rapidity. It is proving to be one of the worst disasters to hit mankind in recent times. The WHO declared it a pandemic on March 11, 2020. On March 24, a "lockdown" was declared by the Government of India, the likes of which we had not experienced in our lifetime. This was aimed to maximize the isolation and quarantine, which provides the best option for containment of an infectious disease with no proven therapy.

The transmissibility and severity of SARS-CoV-2 are compounded by the network of trade routes and extensive communication between countries and people. Urbanization and migration of rural population have led to a population explosion in the cities facilitating easy transmission of the virus.

The pandemics of yore have demonstrated the importance of public health measures like sanitization, social distancing, and quarantine. However, there is an inherent resistance to practice these measures in humans and not without reason.

The enforcement of the lockdown has led to the cancellation of all sociocultural, religious, and political events. There is unemployment, business closures, and a shortage of supplies which has led to panic buying and hoarding. The enormity of the economic consequences will be evident in the coming months but the anxiety and desperation of people are so palpable that it is uncertain how long the lockdown can be sustained.

Nonetheless, it is important to maintain a balance between economic and health concerns. The preparedness of the health sector in coping with the surge of COVID-19 patient numbers that is being projected in the near future is doubtful. The capacity, in terms of hospital beds, healthcare staff, and infrastructure, needs to be enhanced but side by side, the transmission chain has to be
${ }^{1}$ Department of Medicine, IPGMER and SSKM Hospital, Kolkata, West Bengal, India

${ }^{2}$ Department of Medicine, Agartala Government Medical College, Agartala, Tripura, India

Corresponding Author: Nandini Chatterjee, Department of Medicine, IPGMER and SSKM Hospital, Kolkata, West Bengal, India, Phone: +91 8145005804, e-mail: rivuc23092006@gmail.com

How to cite this article: Chatterjee N, Bhattacharya AK. The Crown of Thorns: SARS-CoV-2. Bengal Physician Journal 2020;7(1):1.

Source of support: Nil

Conflict of interest: None

interrupted. Thus handwashing, respiratory hygiene, isolation of cases, and contact tracing are of prime importance and the only cost-effective means to curb the onslaught of this deadly disease.

Last but not the least, is the conduction of research activities to evaluate the spectrum of disease which demonstrates hyper-inflammatory responses and multisystem involvement. Various drugs are being repurposed for chemoprophylaxis and treatment. Hydroxychloroquine, for example, is being projected as an effective chemoprophylactic agent and registries are being created. The use of corticosteroids, an age-old cheap panacea, is showing great promise in suppressing the inflammation triggered by the virus. But this battle cannot be won by drugs only. Awareness, self-care, empathy, and multidisciplinary cooperation are the need of the hour. Whether the vaccine or herd immunity will be our savior in the future is uncertain and only time will tell how this tale unfolds.

(0) The Author(s). 2020 Open Access This article is distributed under the terms of the Creative Commons Attribution 4.0 International License (https:// creativecommons.org/licenses/by-nc/4.0/), which permits unrestricted use, distribution, and non-commercial reproduction in any medium, provided you give appropriate credit to the original author(s) and the source, provide a link to the Creative Commons license, and indicate if changes were made. The Creative Commons Public Domain Dedication waiver (http://creativecommons.org/publicdomain/zero/1.0/) applies to the data made available in this article, unless otherwise stated. 